ACTA MYCOLOGICA

Vol. 41 (1): 55-64

2006
Dedicated to Professor Alina Skirgietto

on the occasion of her ninety fifth birthday

\title{
Laboulbeniales (Ascomycetes) from Latvia
}

\author{
ANDRÉ DE KESEL and INGUNA KRASTINA DE KESEL
}

National Botanic Garden of Belgium, Domein van Bouchout

B 1860 Meise,adk@br.fgov.be

De Kesel A., Krastina De Kesel I.: Laboulbeniales (Ascomycetes) from Latvia. Acta Mycol. 41 (1): 55 64, 2006.

This contribution presents new and historical data on the Laboulbeniales of Latvian Coleoptera. An annotated checklist of 26 taxa is given, 13 are new for Latvia. Only six taxa (accepted names) from Briedis' historical list were found again and six more need to be confirmed as Briedis' material was lost. A neotype is indicated here for the extremely rare Laboulbenia elaphricola Siemaszko et Siemaszko. Its morphology is discussed and compared with Laboulbenia elaphri Spegazzini and Laboulbenia vulgaris Peyr.

Key words: Laboulbeniales, Latvia, Coleoptera, Laboulbenia elaphricola

\section{INTRODUCTION}

Laboulbeniales (Ascomycetes) are strictly parasitic on Arthropoda, mainly insects. Although widespread, information concerning their distribution in Europe is unequal and, as yet, a reflection of the distribution of laboulbeniologists in Europe (Weir, Rossi 1995). The most exhaustive studies were carried out in Spain and Poland, followed by France, Finland, Britain, Italy, Belgium, Germany and Hungary. From other European countries, including the Baltic countries, only very few and isolated reports or collections are available. Records from Estonia and Lithuania have been published in Siemaszko and Siemaszko (1928, 1932), Huldén (1985) and Markovskaja (2000) respectively. In Latvia 16 species of Laboulbeniales have been recorded in the literature (Briedis 1932; Huldén 1985). All species were found on ground beetles (Coleoptera, Carabidae) and all, but one Misgomyces, belong to Laboulbenia. A thorough study of Briedis' material and notes was not possible as it could not be located; we consider it lost.

This paper reports on newly collected material and literature records of Laboulbeniales found on Latvian Coleoptera (Carabidae and Staphylinidae). 


\section{MATERIALS AND METHODS}

Carabidae and Staphylinidae (Coleoptera) were captured by hand or by means of pitfall traps. Sampling sites are situated in Latvia and mainly include river associated forests, riverine marshes and banks along the river Gauja and Abuls (Valmiera raijons). Samples were also taken in the plant debris zones along the shorelines of the Baltic Sea, near Jurmala (Majori) and Pabazi (Balta Kapa). Hosts were killed and stored in 70 or $90 \%$ denaturated ethanol. Screening hosts for infections and preparing of thalli was done using a stereomicroscope at high magnification (25-50x). The thalli were mounted and stained in permanent slides using a medium based on Arabic gum with cotton blue and a trace of glycerine (De Kesel 1998). Field data (locality, GPS-coordinates, date and habitat), host data (taxon, gender and infection site) and parasite data (taxon, number of specimens and development) were recorded. Slide(s) from the Laboulbeniales and the corresponding hosts were given the same number (i.e. DKK-number); all material and notes are deposited at BR (Herbarium National Botanic Garden of Belgium). When specific identity of a host was doubtful only the generic name of the host was used, followed by sp. The generic taxonomy of Staphylinidae follows Lo h se (1964) and Lo h se et al. (1974), for Carabidae Lindroth (1974) or Fre ude (1976).

Nomenclature and identification of all Laboulbeniales found in Latvia is largely based on 'The Laboulbeniales of Poland' by T. Majewski (1994). We consider it a key reference work for the study of the Laboulbeniales from the Baltics. To avoid redundancy we refrained from giving exhaustive species descriptions and comments, unless complementary to the information given in Majewski (l.c.) or elsewhere.

\section{RESULTS}

Annotated and preliminary checklist of the Laboulbeniales from Latvia

In the following checklist we placed species in bold when they correspond with verified records, i.e. species found by us in 2004-2005 and with reference material in Herbarium BR. Species marked with an * are new for Latvia. Species in normal case have been mentioned in Brie dis (1932); their presence in Latvia awaits confirmation.

Aphanandromyces audisioi W. Rossi*

- On Brachypterus urticae (Fabricius) (Coleoptera, Nitidulidae). DKK5-6: Valmiera, Gauja, tributary Misa, 11.08.2004, N57 $31.66^{\prime}-\mathrm{E} 025^{\circ} 26.47^{\prime}$, on flowers of $U r$ tica. Thalli were found on the elytra and the abdominal tergites of the hosts.

Euzodiomyces lathrobii Thaxt.*

- On Lathrobium sp. (Coleoptera, Staphylinidae). DKK17: Valmiera, Gauja, trib-

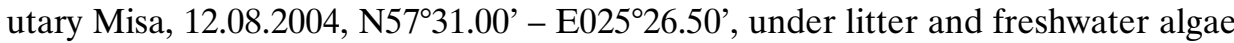
along rivulet banks. Thalli occur on the edges of the elytra.

Haplomyces texanus Thaxt.*

- On Bledius sp. (Coleoptera, Staphylinidae). DKK9: Valmiera, Gauja, 05.08.2004, N57 $31.66^{\prime}$ - E025 $26.47^{\prime}$, riverside. Thalli were found on the last abdominal tergite.

Laboulbenia argutoris Cépède, Picard*

- On Pterostichus diligens (Sturm) (Coleoptera, Carabidae). DKK48: Pabazi, 


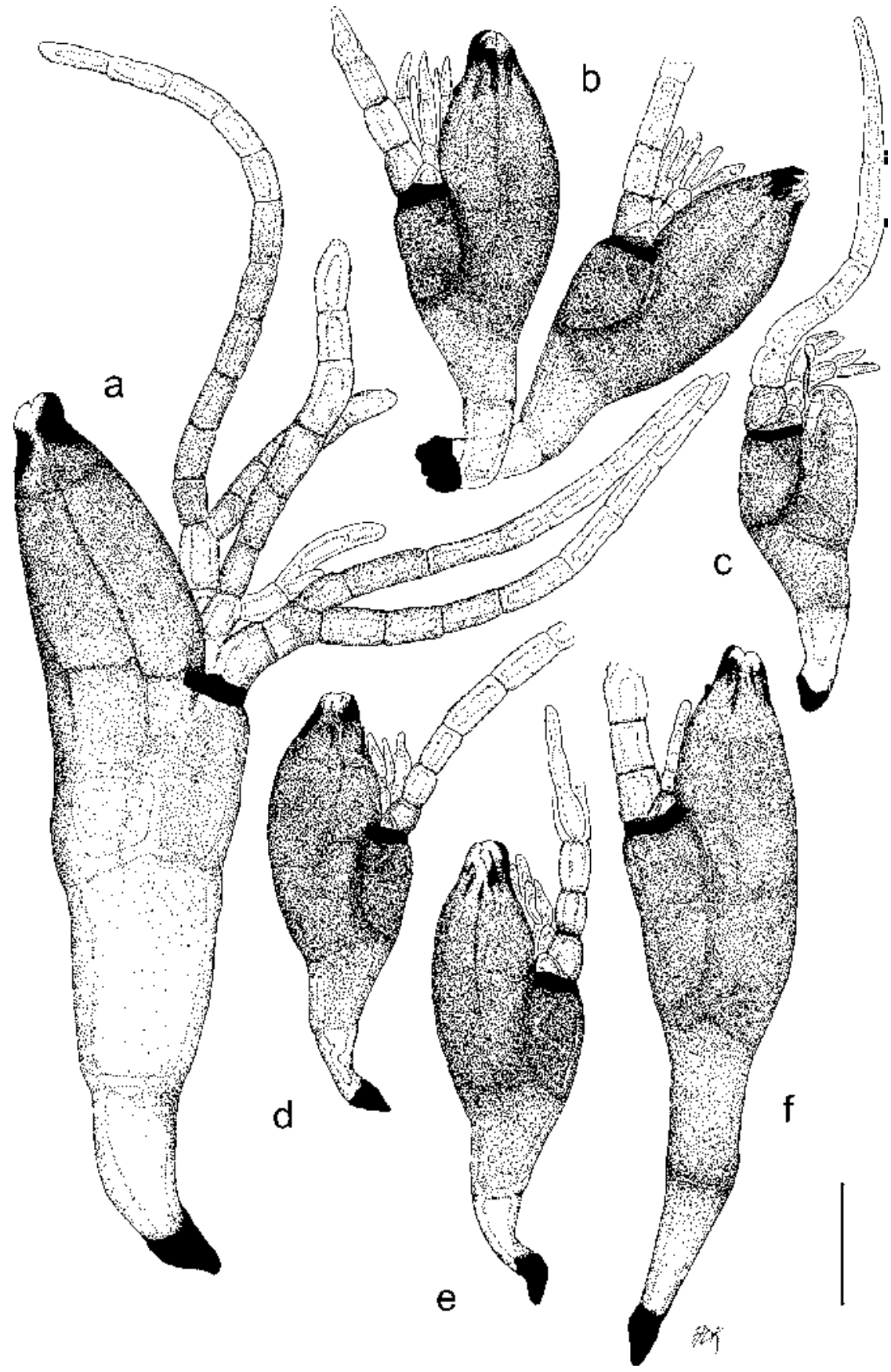

Fig. 1. a. Laboulbenia elaphri Spegazzini from pronotum of male Elaphrus cupreus (DKK43); b e. Laboulbenia elaphricola Siemaszko et Siemaszko, with b,d \& e. from pronotum of male Elaphrus riparius (DKK62) and c. juvenile thallus with typical stout habit, taken from right elytron of female Elaphrus riparius (DKK38b); f. Laboulbenia vulgaris Peyr. from elytron of female Bembidion sp. (DKK44). Scale bar $=50 \mu \mathrm{m}$. 


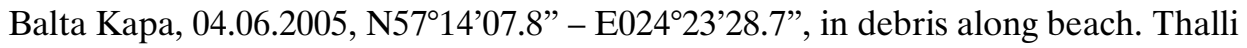
were found on the elytra.

- On Pterostichus sp. (Coleoptera, Carabidae). DKK40: Brenguli, river Abuls, 31.05.2005, N57 32'56.2” - E025'32'24.3”, along rivulet bank in forested area. Thalli were found on the elytra.

Laboulbenia calathi Majewski

- On Calathus melanocephalus L., in Zilupe (Brie d is 1932)

Laboulbenia clivinalis Thaxt.

- On Clivina fossor L. (Coleoptera, Carabidae), in Valka, Latgale and Zilupe (Briedis 1932)

- On Clivina fossor L. DKK23: Jurmala, Majori, 02.06.2005, N5658' - E023ํㄴ', in plant debris along the beach; DKK26: Valmiera, Gauja, 03.06.2005, N57³2'21.6" - E025 26'44.3", river bank with pioneer vegetation of willows; DKK46: Pabazi, Bal-

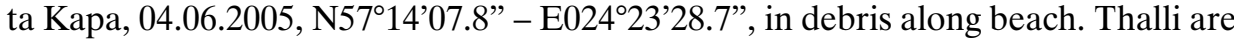
commonly found on both elytra and the metathorax.

Laboulbenia cristata Thaxt.*

- On Paederus cf. riparius (Coleoptera, Staphylinidae). DKK45: Pabazi, Balta

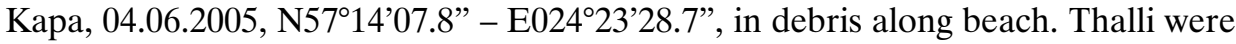
found on the abdominal tergites, well protected by the elytra.

Laboulbenia dubia Thaxt.

- On Philonthus fuscipennis Mannh. and Philonthus sp., (Coleoptera, Staphylinidae), in Zilupe (Brie dis 1932).

Laboulbenia elaphri Spegazzini*

- On Elaphrus cupreus Dufts. (Coleoptera, Carabidae). DKK25(a,b,c,d), DKK28:

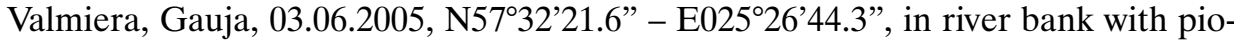
neer vegetation of willows; DKK43: Brenguli, river Abuls, 31.05.2005, N57³2'56.2" - E025'32'24.3", along rivulet bank. Thalli were found on the right elytron, the pronotum and the mandibula. Thalli from the latter spot have a smaller lower receptaculum and exhibit a more stout habitus.

Laboulbenia elaphricola Siemaszko et Siemaszko *

- On Elaphrus riparius (L.) (Coleoptera, Carabidae). DKK38(a,b): Valmiera, Gauja, tributary Misa, 04.06.2005, N57 $31.08^{\prime}$ - E025 $26.52^{\prime}$, under litter, along rivulet bank in forested zone; DKK61, DKK62, DKK66: ibidem s.l., 03.06.2005, N57 32"0.5" - E025'26'49.2”, along rivulet banks; DKK42: Brenguli, river Abuls, 31.05.2005, N57 32'56.2” - E025 32'24.3", along rivulet bank in forested area. Thalli are found all over the hosts' integuments, but most thalli occur on the elytra and the pronotum.

Laboulbenia elaphricola was described by Sie maszko and Sie maszko in 1928 (Pol. Pismo Entomol. 6, pg. 200, T.VII, Fig. 2). It was found in Eastern Poland, Pulawy, on Elaphrus riparius L. The original description is very short and the drawing of the type represents a damaged and incomplete outer appendage. The type material was unfortunately lost during WWII (Majewski 1994). Since its description only Bành e gyi (1950) reported L. elaphricola, but stated later that his material belongs to L. elaphri (Bàn h e gyi 1964). L. elaphricola seems to be a very rare species, because very intensive screening of suitable habitats in Eastern Poland, Bialowieza (Majewski 2003) did not supply new material. Today it is a species with an uncertain status. In the absence of information on its full morphology and eventual posi- 
tion related variations, Bành egyi (1964) and Majewski (1994) suggested that it could just be a growth form of the more common Laboulbenia elaphri Spegazzini.

The numerous specimens we could collect on Elaphrus riparius from Latvia correspond with L. elaphricola. Our material confirms that this species is not a growth form of L. elaphri as its typical short and stout thalli occur invariably on different parts of the hosts' integument. L. elaphricola is indeed a small and dark species and no forms, even closely resembling L. elaphri, were seen on the studied hosts. We consider Siemaszko and Siemaszko's L. elaphricola a good species. It is very distinct from $L$. elaphri and actually close to L. vulgaris, as already stated by Siemaszko and Siemaszko (1928). The following diagnosis and figure 1 should help to separate it from L. vulgaris.

- All thalli of L. elaphricola are small and stout, invariably of their origin on the host. They are never longer than $220 \mu \mathrm{m}$ (foot-ostiolum).

- Already in an early stage of development L. elaphricola shows a deep pigmentation of the receptaculum. Except for the poorly and uniformly pigmented cell I, cell II and septum I-II, all adult specimens have a deeply pigmented to blackish thallus. In L. vulgaris the septum I-II is often darker, a feature that lacks in L. elaphricola.

- The perithecium is more free in L. elaphricola than in L. vulgaris, i.e. the insertion cell and cell $\mathrm{V}$ always being slightly below the middle of the perithecium in $L$. elaphricola.

- Cell II of L. elaphricola almost immediately widens upwards, forming a strikingly long septum with cell VI and a short septum with cell III. Cell VI is much broader than high. In most cases the septum II-VI is at least twice the length of septum II-III.

- The upper receptacle, i.e. the complex of cells III, IV and V, is delimited or demarcated from the rest of the thallus by a very deeply pigmented line, even in very young thalli. This darkened line starts at the anterior side of the insertion cell (close to the perithecium). It continues downwards along the adaxial septa of cell V, cell IV and cell III, makes a curves along the basal septum of the latter, to finally end at the posterior (dorsal) side of the receptacle.

- The outer appendage is not branched and relatively long. In many cases, but not always, the three basal cells of the outer appendage tend to be slightly inflated.

Specimens with a branched outer appendage occur very rarely and only as a result of damage and subsequent atypical regeneration of the appendage. The inner appendage is branched once or twice and never exceeding the ostiolum.

- $\quad$ The insertion cell is constricted, sometimes strongly.

The name bearing type material of L. elaphricola is lost and since its description L. elaphricola was not found again in Poland or elsewhere (Majewski pers. comm.). In this context we indicate our collection DKK62 (kept at BR) from Latvia as neotype for Laboulbenia elaphricola Siemaszko et Siemaszko. This material was obtained from the elytra of Elaphrus riparius L., caught on 03.VI.2005 along the forested banks of a tributary of the river Gauja in Valmiera (Latvia, N57 31.08' - E025 26.52').

Laboulbenia fasciculata Peyr.

- On Patrobus excavatus Payk. (Coleoptera, Carabidae), in Ogre, Valka and Valmiera (Bried is 1932)

- On Patrobus atrorufus (Stroem), DKK3 \& 4: Valmiera, Gauja, tributary Misa, 11.08.2004, N57³1.66' - E02526.47', under debris along rivulet; DKK18, 19, 21: ibi- 
dem, 12.08.2004. Thalli occur on all parts of the integument, some hosts are heavily infected, carrying over 200 thalli.

Laboulbenia flagellata Peyr.

- On Agonum albipes Fabr. (as Platynus ruficornis Goeze), (Coleoptera, Carabidae), in Koknese and Ogre (Brie dis 1932)

- On Agonum assimile (Paykull) (Coleoptera, Carabidae). DKK41: Brenguli, river Abuls, 31.05.2005, N57³2'56.2" - E025'32'24.3", along rivulet bank in forested area; DKK52(a,b), DKK63: Valmiera, Gauja, tributary Misa, 03.06.2005, N57 $32 " 0.5 "$ - E025 26'49.2", along rivulet banks. Infections occur on the upper part of the exoskeleton, i.e. the pronotum and both elytra.

- On Agonum viduum (Panzer) (Coleoptera, Carabidae). DKK68: Valmiera, Gauja, tributary Misa, 10.08.2005, N57 32”0.5” - E025'26'49.2”, in plant debris. Thalli were found on the elytra.

- On Agonum sp. (Coleoptera, Carabidae). DKK22: Valmiera, Gauja, tributary Misa, 10.08.2004, N57 $31.00^{\prime}-\mathrm{E} 025^{\circ} 26.50^{\prime}$, under litter along rivulet banks. Thalli occur on all parts of the integument.

- On Bembidion adustum Schaum., B. ustulatum L. and Bembidion sp., in Valka (Briedis 1932)

- On Bembidion fluviatile L., in Valmiera (Brie dis 1932)

Remark: Briedis (1932) reports mixed infection with L. luxurians, L. pedicellata and L. vulgaris. The presence of Laboulbenia flagellata on Bembidion is however doubtful and hitherto not mentioned on any species of Bembidion in Europe (Santamaría et al. 1991; Majewski 1994).

Laboulbenia filifera Thaxt.

- On Harpalus aeneus Fabr. (Coleoptera, Carabidae), in Valka (Brie dis 1932)

Laboulbenia hyalopoda De Kesel *

- On Dromius linearis (Olivier) (Coleoptera, Carabidae). DKK69: Valmiera,

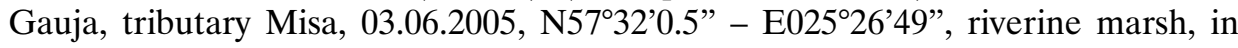
dead stem of Heracleum cf. sphondylium L. (Hogweed). Despite their length, thalli are very easily overlooked. They were found on the caudal extremity (soft parts) of the last abdominal segment.

Thallus very slender, hyaline to yellowish, up to $390 \mu \mathrm{m}$ long. Receptaculum slender, $210 \mu \mathrm{m}$ high. Cell I and II three to four times higher than broad, without pigmentation. Base of cell I not pigmented; foot hyaline, with one or two small brownish spots. Cell III and IV about the same height (20-25 $\mu \mathrm{m})$, two times higher than broad. Adaxial side of cell V free from the perithecium. Cell V triangular, slightly rounded, half as high as cell IV. Insertion cell amber to dark brown, moderately constricted. Abaxial (outer) appendage straight, not branched, up to $80 \mu \mathrm{m}$ long, probably longer in undamaged specimens, not pigmented and without dark septa; parafysopodium (basal cell of outer appendage) similar to other cells, up to $20 \mu \mathrm{m}$ high. Adaxial (inner) appendage hardly pigmented, up to $80 \mu \mathrm{m}$ long; andropodium up to $8 \mu \mathrm{m}$ long, bearing two simple appendages. Antheridia not seen. Cell VI smaller than cell III, easily distinguished as is the rest of the perithecial basal cells. Perithecium long, slender and slightly asymmetrically curved, $180 \times 32 \mu \mathrm{m}$, widest below the middle, hyaline, without or almost without pigmentation at the abaxial side; perithecial apex is differentiated in a $70 \mu \mathrm{m}$ long and slender abaxially bent 
neck. Ostiolum hyaline, consisting of 4 strongly inflated cells (lips), the most adaxial cell (lip) up to $20 \mu \mathrm{m}$ shorter than the others.

Laboulbenia luxurians Thaxt.

- On Bembidion adustum Schaum, (Coleoptera, Carabidae), in Sigulda (Briedis 1932)

- On Bembidion dentellum (Thunb.) (Coleoptera, Carabidae). DKK53 (mixed with L. vulgaris): Valmiera, Gauja, tributary Misa, 03.06.2005, N57³2"0.5" E025'26'49.2", along rivulet banks. Thalli occur on the abdomen.

- On Bembidion littorale Oliv. (Coleoptera, Carabidae), in Ogre (Briedis 1932)

- On Bembidion tetracolum Say. (Coleoptera, Carabidae). DKK54, DKK55(a,b), DKK58(a), DKK59, DKK65 (mixed with L. vulgaris): Valmiera, Gauja, tributary Misa, 03.06.2005, N57³2”0.5” - E025 26'49.2”, along rivulet banks. Thalli were found on all body parts, often on the pronotum, the elytra, the prothorax and the legs.

- On Bembidion ustulatum Duft., B. andreae Er., in Sigulda (B ri e dis 1932)

Remarks: Briedis (1932) reports mixed infection with L. flagellata, L. pedicellata and L. vulgaris. In our material mixed infections were only observed on Bembidion dentellum and Bembidion tetracolum, i.e. mixed with L. vulgaris (see DKK53 and DKK58(a,b) \& DKK65 respectively).

Laboulbenia pedicellata Thaxt.

- On Dyschirius globosus Herbst (Coleoptera, Carabidae), in Zilupe (Briedis 1932)

- On Dyschirius thoracicus (Rossi) (Coleoptera, Carabidae), in Riga and Sigulda (Huldén 1985)

- On Dyschirius sp. (Coleoptera, Carabidae). DKK10, DKK13: Valmiera, Gauja, 05.08.2004, N57 31.66' -E025 26.47', along de riverside; DKK30(b), DKK31, DKK36, DKK37(a,b): Valmiera, Gauja, 03.06.2005, N57³2’22.1” - E025'26’41.3”, riverside, on sand ; DKK50 : Pabazi, Balta Kapa, 04.06.2005, N57¹4'07.8” - E024²3'28.7', in debris along beach. Thalli occur on the elytra, the pro- and metathorax and tibia.

- On Bembidion adustum Schaum (Coleoptera, Carabidae), in Valka (Brie dis 1932)

- On Bembidion sp. (Coleoptera, Carabidae), DKK11,12: Valmiera, Gauja, 05.08.2004, N57³1.66' - E025²6.47', along de riverside ; DKK24: Jurmala, Majori, 02.06.2005, N56 $58^{\prime}$ - E023 45', in plant debris along the beach; DKK51: Pabazi, Balta Kapa, 04.06.2005, N57¹4'07.8' - E024²3'28.7', in debris along beach. Thalli occur on the legs (femur) and the elytra.

Laboulbenia philonthi Thaxt.*

- On Philonthus sp. (Coleoptera, Staphylinidae). DKK8: Valmiera, Gauja, 05.08.2004, N57 31.6' - E025 26.5', along the shoreline; DKK27: Valmiera, Gauja,

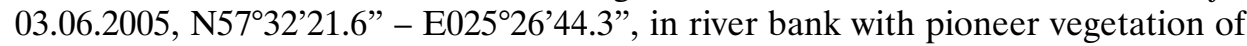
willows.; DKK29: Valmiera, Gauja, 03.06.2005, N57³2’22.1” - E025²6’41.3”, riverside, on sand. Thalli were found on the abdominal tergites and the cephalon.

Laboulbenia pseudomasei Thaxt. *

- On Pterostichus nigrita (Payk.) (Coleoptera, Carabidae). DKK47 : Pabazi, Balta Kapa, 04.06.2005, N57¹4'07.8” - E024²3'28.7”, in debris along beach; DKK60, 
DKK64: Valmiera, Gauja, tributary Misa, 03.06.2005, N57³2”0.5” - E02526’49.2”, along rivulet banks. Thalli were found on the elytra, the pro- and metathorax. Proliferation of appendages is very common in adult thalli.

- On Pterostichus sp., DKK1-2: Valmiera, Gauja, tributary Misa, 11.08.2004, N57³1.66' - E025 26.47', under debris along rivulet; DKK20: ibidem, 12.08.2004. Thalli were found on various parts of the integument, i.e. legs, pronotum and both elytra.

Laboulbenia rigida Thaxt.

- On Pterostichus nigrita (Payk.) (Coleoptera, Carabidae), in Valka (Briedis 1932)

Laboulbenia rougetii Montagne, Robin

- On Chlaenius vestitus Payk. (Coleoptera, Carabidae), near Ogre (Briedis 1932)

Laboulbenia thaxteri Cépède, Picard

- On Asaphidion flavipes (L.) (Coleoptera, Carabidae), in Sigulda (Huldén 1985)

Laboulbenia vulgaris Peyr.

- On Bembidion andreae Er. (Coleoptera, Carabidae), in Valmiera (Briedis 1932)

- On Bembidion dentellum (Thunb.). DKK53 (mixed with L. luxurians): Valmiera, Gauja, tributary Misa, 03.06.2005, N57³2”0.5” - E02526'49.2”, along rivulet banks. Thalli occurred on the abdomen.

- On Bembidion lunatum Duft. (Coleoptera, Carabidae), in Sigulda (Bried is 1932)

- On Bembidion saxatile Gyll. (Coleoptera, Carabidae), in Valka (Brie d is 1932)

- On Bembidion tetracolum Say. (Coleoptera, Carabidae), DKK56, DKK57, DKK58(b), DKK65 (mixed with L. luxurians): Valmiera, Gauja, tributary Misa, 03.06.2005, N57³2”0.5" - E025 26'49.2”, along rivulet banks. Thalli were observed on the pronotum, the elytra and to a lesser degree also on the legs.

- On Bembidion sp. (Coleoptera, Carabidae). DKK39: Valmiera, Gauja, tributary Misa, 04.06.2005, N57³1.08' - E025 26.52', under litter, along rivulet bank in forested zone; DKK44: Brenguli, river Abuls, 31.05.2005, N57³2'56.2” - E02532'24.3”, along rivulet bank in forested area. Hosts are infected on the elytra.

Remark: mixed infections with Laboulbenia luxurians are often observed on Bembidion tetracolum (cf. DKK65).

Misgomyces dyschirii Thaxt.

- On Dyschirius globosus (Herbst.) (Coleoptera, Carabidae): in Sigulda and Jugla (Huldén 1985)

- On Dyschirius sp. DKK30(a): Valmiera, Gauja, 03.06.2005, N57³2’22.1” E025²6'41.3”, riverside, on sand; DKK35: ibidem s.l., N57³2’21.6” - E02526'44.3”, sandy shores of Gauja. Thalli were found in the side edges from the elytra.

Monoicomyces brittanicus Thaxt. *

- On Atheta sp. (Coleoptera, Staphylinidae, Aleocharinae). DKK49(a,b,c): Pabazi, Balta Kapa, 04.06.2005, N57 14'07.8” - E024²3'28.7”, in debris along the beach. An easily overlooked species. Thalli were growing on the cephalon, between the antennae. 
Peyritschiella protea Thaxt.*

- On Anotylus sp. (Coleoptera, Staphylinidae). DKK32(a,b), DKK33: Valmiera, Gauja, 03.06.2005, N57³2'21.6” - E025²6'44.3”, river bank with pioneer vegetation of Salix sp. Thalli occur on the antennae, the legs and metasternum.

Rhadinomyces cristatus Thaxt.*

- On Lathrobium sp. (Coleoptera, Staphylinidae). DKK15, 16: Valmiera, Gauja, tributary Misa, 12.08.2004, N57 $31.00^{\prime}$ - E025 26.50', under litter and freshwater algae along rivulet banks. Thalli occur on the metasternum, abdominal tergites and some of the coxae.

\section{SYNONYMS AND DOUBTFUL OR EXCLUDED RECORDS MENTIONED IN BRIEDIS (1932)}

The species listed below represent historical records from Briedis (1932). All these taxa were either reduced into synonymy (S a n t a maria et al. 1991 or Majew ski 1994) or should be considered as doubtful records in the studied area.

1. Laboulbenia brachiata Thaxt. L. fasciculata Peyr.

2. Laboulbenia elongata Thaxt. L. flagellata Peyr.

3. Laboulbenia europaea Thaxt. L. rougetii Montagne, Robin

4. Laboulbenia fumosa Thaxt.

- On Agonum piceum L., in Valka

5. Laboulbenia harpali Thaxt.

- On Harpalus pubescens Müll., in Zilupe

- On Harpalus tardus Panz., H. hirtipes Panz., H. aeneus Fabr., in Valka

6. Laboulbenia parvula Thaxt. doubtful in Europe (S a nta maría et al. 1991)

- On Agonum assimile (as Platynus assimilis Payk.), near Valka

7. Laboulbenia polyphaga Thaxt., i.e. var. calathicola probably to be considered a record of L. calathi

\section{CONCLUSIONS}

- Twenty six species are reported for Latvia, 13 are new for the studied territory.

- Six species reported by Brie dis (1932) were confirmed.

- The presence of six more species, reported by Briedis (1932) and Huldén (1985), needs to be confirmed with new material as Briedis' original material from Latvia is untraceable.

- Laboulbenia elaphricola Siemaszko et Siemaszko is reported for Latvia. This taxon is extremely rare and not reported, with certainty, since its discovery. It has an uncertain status because of a very short original diagnosis. The name bearing type was unfortunately lost and L. elaphricola is currently considered a growth form of $L$. elaphri. The Latvian material, however, provides enough evidence that L. elaphricola is a good species. 


\section{REFERENCES}

B á n h e gy i J. 1950. Ritka Laboulbeniák a Kárpátmedencéböl (Laboulbeniales rares du Bassin Carpatique). Ann. Biol. Univ. Budapest. (Budapesti Tudományegyetem Biol. intézeteinek Évkönyve) 1: 189196.

Bán h e gy i J. 1964. Notes sur quelques Laboulbéniacées de la Pologne. Ann. Univ. Sci. Budapest. Rolando Eötvös, Sect. Biol. 7: 1927.

Brie dis A. 1932. Laboulbeniaceae in Latvia (preliminary note). Acta Horti Botanici Universitatis Latvien sis 7: 131134 .

De Kesel A. 1998. Identificatie en gastheerspectrum van het genus Laboulbenia in België (Ascomycetes, Laboulbeniales). Sterbeeckia 18:13 31.

Fre u de H. 1976. Familie Carabidae (Laufkäfer). (In:) H. Fre u de, K. W. Harde, G. A. Lo h se (eds). Die Käfer mitteleuropas. 2. Adephaga 1. Goecke, Evers Verlag, Krefeld, Germany. 302pp.

Hu ldén L. 1985. Floristic notes on Palaearctic Laboulbeniales (Ascomycetes). Karstenia 25: 116.

Lin d r ot h C.H. 1974. Handbooks for the identification of British insects. Vol. IV, part 2: Coleoptera, Cara bidae. Royal Entomological Society of London. United Kingdom. 148pp.

Lo h s e G. 1964. Staphylinidae I (Micropeplinae bis Tachyporinae). (In:) Freude H., Harde K.W., Lohse G.A. Die Käfer Mitteleuropas IV. Goecke, Evers, Krefeld, Germany. 264 pp.

Lohse G., Benick G., Likowski Z. 1974. Staphylinidae II (Hypocyphtinae und Aleocharinae). Pselap hidae. (In:) Fre u d e H., Harde K.W., Lo hs e G.A. Die Käfer Mitteleuropas V. Goecke, Evers, Krefeld, Germany. 381 pp.

Majewski T. 1994. The Laboulbeniales of Poland. Polish Bot. Stud. 7: 3466.

Majews ki T. 2003. Distribution and ecology of Laboulbeniales (Fungi, Ascomycetes) in the Bialowieza for est and its western foreland. Phytocoenosis Vol. 15 (N.S.) 2003. Supplementum Cartographiae Geobo tanicae 16 Warszawa Bialowieża. 144 pp.

Markovskaja S. 2000. Data on Lithuanian Laboulbeniales. Botanica Lithuanica 6 (3): 299311.

Santamaria S., Balazuc J., Tavare s I.I. 1991. Distribution of the European Laboulbeniales (Fungi, Ascomycotina). An annotated list of species. Treballs de l'Institut Botánic de Barcelona 14: 1123.

Sie maszko J., Sie maszko W. 1928. Owadorosty polskie i palearktyczne. (Laboulbeniales polonici et palaearctici.) Polskie Pismo Entomol. 6: 188 211. Tav. VII.

Sie maszko J., Sie maszko W. 1932. Owadorosty polskie i palearktyczne. (Laboulbeniales polonici et palaearctici.). II. Polskie Pismo Entomol. 10: 149 188. Tab. VII X.

We ir A., Rossi W. 1995. Laboulbeniales parasitic on British Diptera. Mycol. Res. 99 (7): 841849.

\section{Gatunki Laboulbeniales (Ascomycetes) z terenu Lotwy}

\section{Streszczenie}

W artykule przedstawiono zarówno nowe jak i historyczne dane o gatunkach Laboulbe niales występujących na łotewskich Coleoptera, przede wszystkim na Carabidae i Staphyli nidae. Odnotowano 26 gatunków, z których 13 jest nowych dla Łotwy. Pierwsza lista gatun ków Laboulbeniales z Łotwy została opublikowana w roku 1932 przez Briedisa w Acta Horti Botanici Universitatis Latviensis. Kolekcja Briedisa najprawdopodobniej zaginęła. Sześć po twierdzonych taksonów z listy Briedisa zostało na nowo odnalezionych, a dalsze sześć należy odszukać. Krytyczna lista 26 gatunków zawiera również uwagi taksonomiczne dotyczące m. in. Laboulbenia elaphricola Siemaszko et Siemaszko. 